\title{
Optimizing the Use of Village Funds and Efforts to Develop Village-Owned Enterprises in South Central Timor Regency
}

\author{
Jennie S. Sir ${ }^{1}$, Selfesina Samadara ${ }^{1}$, Deetje W. Manuain ${ }^{1}$ \\ \{jenniesir678@gmail.com, selfi_samadara@yahoo.com,d3c3_manuain@yahoo.com\} \\ Politeknik Negeri Kupang ${ }^{1}$
}

\begin{abstract}
The purpose of this study is to map the potential of the village, and analyze the use of village funds by measuring the effectiveness and efficiency of village financial management, so that benefits can be obtained for economic progress in the region. Responsible use of village funds is the main focus of this research, so it is hoped that a Village-Owned Enterprise (BUMDes) can be formed which leads to an increase in Village Original Revenue (PADes). Research method used was qualitative and quantitative method with case study approach. The sample used was villages in Kecamatan Kota Soe, where village officials were the main informants. The results showed that the Kuatae and Noemeto Villages had been effective in absorbing the Village Fund budget, but were not yet efficient in managing the Village Fund. The results of this study also show that the potential of Kuatae and Noemeto villages is very diverse, but cannot be managed optimally. The role of the BUMDes has not yet been felt by the community so it needs better structuring and planning in the management of the Village Fund so that it benefits the community.
\end{abstract}

Keywords: Village funds, BUMDes, PADes.

\section{Introduction}

The village is a legal community unit that has the authority to manage and manage government affairs, and community interests based on: community initiatives, original rights, and / or traditional rights that are recognized and respected in the system of government of the Unitary Republic of Indonesia [1]. The Village Law has placed the village as the spearhead of development and improvement of people's welfare. Villages are given adequate authority and sources of funds to be able to manage their potential to improve the economy and welfare of the community. Village development can be enhanced by: empowering the local economy, creating access to local transportation to rural areas, and accelerating the fulfillment of basic infrastructure.

In order to support the implementation of village functions and functions in the administration of government and village development in all aspects in accordance with their authority, Law No. 6 of 2014 gives a mandate to the Government to allocate Village Funds. The Village Fund is budgeted every year in the APBN given to each village as one source of village income. This policy also integrates and optimizes all budget allocation schemes from the Government to villages that have already existed. The Village Fund is intended for Villages and Indigenous Villages that are transferred through the Regency / City APBD and allocated to each village equally and fairly [2]. 
Every year the Central Government has budgeted Village Funds large enough to be given to villages. The government has budgeted a total of 5 years of village funds from 2015 to 2019 of Rp. 257 trillion, and has never declined every year. The details are Rp. 20.67 trillion (2015), Rp. 46.98 trillion (2016), Rp. 60 trillion (2017), Rp. 60 trillion (2018), and Rp. 70 trillion (2019). The village funds are given to all villages in Indonesia with a 77 percent formula divided equally to all villages. Then 20 percent is allocated to supplement proportionally to villages based on population, poverty level, geographical difficulty level and area size. Then, three percent is allocated for additional funds to villages that are lagging behind [3].

In accordance with Permendes No. 19 of 2017, the priority for the use of Village Funds is for village development and village community empowerment. The field of village development is directed at Procurement, Development, Development and Maintenance of facilities and infrastructure: Village, basic social services, village economic endeavors, environment, and others. While the field of community empowerment is directed to [4]:

a. Increasing community participation in village development planning, implementation and supervision;

b. Capacity building and resilience of rural communities;

c. Development of village information systems;

d. Support management of basic social service activities;

e. Capital support and management of productive economic ventures;

f. Support management of economic businesses;

g. Support management of environmental preservation;

h. Development of cooperation between villages and village cooperation with third parties;

i. Support to face and deal with natural disasters and other outbreaks;

j. Other fields of activity.

East Nusa Tenggara Province as an area that has 3,048 villages, with 1,094 villages (35.89\%), 1,945 developing villages $(63.81 \%)$, and 9 independent villages $(0.30 \%)$ [5]. This shows that there are still many villages in NTT Province that need special attention in order to increase to become independent villages. The role of village funds is very important in encouraging villages in NTT to become more advanced and prosperous. From 2015 to 2018 , village funds received from the Central Government have increased every year. In 2015, the amount of village funds received was IDR 813 billion, in 2016 IDR 1.84 trillion, in 2017 IDR 2.36 trillion, then in 2018 IDR 2.5 trillion. Even in 2019, the government has budgeted Rp 3.03 trillion in village funds where the region with the largest allocation of village funds was the South Central Timor District (TTS), which amounted to Rp 287 billion, followed by Southwest Sumba amounting to Rp 231 billion, and Manggarai Regency and Ende of Rp. 198 billion [6].

It is important to conduct a study of the use of village funds in TTS because as one of the districts that has a significant number of disadvantaged villages, TTS also has not explored much of the potential in the villages, so that there are only 95 BUMDes out of 266 villages in the TTS region [7]. Several previous studies examined the transparency and accountability of Village Fund management [8] [9] [10] and found that the village officers have not fully understood and understood implementation of village accounting [11], so it was very important to analyze the Village Funds accountability report, to conduct village funds misuse prevention [12].

This research aimed to evaluate the use of village funds in TTS as the district that receives the largest contribution of village funds in NTT. Village funds as a supporter of development and economic activities in the village often experience problems, especially related to the distribution of village funds which are often late, due to reporting and accountability for the 
improper use of village funds. This research will also map the village potentials that can support the development of BUMDes, so as to increase the village's original income. To move the economy in the village which is characterized by a collective spirit and mutual cooperation, the village can establish a village-owned enterprise abbreviated as BUMDes. BUMDes is a business entity whose entire / most of the capital is owned by the Village, through direct participation of the assets of the Village which is separated to manage assets, services, and other businesses, for the welfare of the Village community. The purpose of BUMDes is to increase the community's ability to control the economy of the village for the greatest welfare of the community; and economic independence at the village level. Establishment of BUMDes was agreed through village deliberations, and determined by Village Regulations.

BUMDes is managed with a family spirit and mutual cooperation. BUMDes can conduct business in the economy and / or public services in accordance with statutory provisions. Establishment of BUMDes can be done only for the scope of one village or BUMDes together in the scope between villages.

Establishment of BUMDes is intended to carry out the tasks of the Village in organizing production branches that are important for the Village and which control the livelihoods of many people. BUMDes business results are utilized for: business development, village development, empowerment of village communities, and providing assistance to the poor through grants, social assistance, and revolving fund activities stipulated in the Village Revenue and Expenditure Budget (APBDes) [13].

Establishment of BUMDes in Kuatae and Noemeto villages is in line with the provincial government program to motivate each village to produce superior commodities such as the weaving industry, agricultural products, plantations, and livestock, and in the end some independent villages in the TTS Regency region can become pilot villages for villages other villages in the TTS Regency and NTT in general. So that the purpose of rural area development in realizing community independence, and creating independent and sustainable villages, can be realized.

\section{Methods}

This research is focused on optimizing the use of Village Funds in an effort to develop Village-Owned Enterprises and aims to increase Village Original Income. This study uses a quantitative descriptive method that is strengthened by using a qualitative approach in analysis.

The data used in this study are secondary data from the Village Community Empowerment Agency (BPMD) of the TTS district and literature survey. While the data analyzed quantitatively in empirical observations are data sourced from the Village Budget (APBDes), SPJ and other data directly related to the Village Fund. To assess the effectiveness and efficiency of the use of village funds the following formulation is used [14]:

$$
\text { Efficiency Ratio = Output / Input x 100\% }
$$

$$
\text { Effectiveness Ratio = Outcome / Output x 100\% }
$$

The use of primary data in this study is data from observations and interviews with village officials involved in village financial management, such as: village heads, village secretaries, treasurers, and related parties. In addition, this study also uses data sourced from literature 
surveys and studies that have been done before, so that the data can strengthen the analysis qualitatively.

The villages that were the objects of this research were Kuatae Village and Noemeto Village, which are located in Soe City Subdistrict, South Central Timor Regency, NTT. Both of these villages have the potential for natural wealth, but have not been optimized so it is very important to have a Village-Owned Enterprises (BUMDes) as a market place that is useful in improving the economy of the village community. Currently Kuatae Village and Noemeto Village are in the process of forming a BUMDes.

This research flow includes: assessment of the effectiveness and efficiency of the use of Village Funds, extracting the potential of village-owned resources, and the development of BUMDes in an effort to increase Village Original Income.

Data collection in this research was carried out through observation / field studies, interviews with related parties, and collection of supporting documents. Observation / field studies allow researchers to appreciate the actual conditions of the subjects studied, and allow researchers to act as data sources. In this case, the researcher is in the position of participatory observation, in which the researcher also participates in the participant's daily activities and hopes to gather more information through their actions and behavior. Interviews were conducted to explore more deeply information from related parties, through repeated face-to-face meetings between researchers and informants directed at efforts to understand the informant's perspective in their life, experience or situation when they express it through words [15].

The documents referred to in this study are all notes in the form of hardcopy or softcopy. The researcher will review documents related to the research being carried out. These documents are the duties and functions of the Village, regulations relating to village funds, community complaints about the management of the Village Fund in 2016-2018, and accountability reports on the use of the Village Fund in 2016-2018. Triangulation techniques are also used in data analysis procedures, through three stages of activity namely, data reduction, data presentation, and drawing conclusions [16].

\section{Results and Discussion}

\subsection{Effectiveness and Efficiency of Village Fund Management}

Kuatae and Noemeto villages are located in Soe City Subdistrict, TTS Regency, East Nusa Tenggara, located at an altitude of 500 meters above sea level with a hilly texture, so that this region is more dominated by mountain air that tends to cool. Nevertheless, the rainfall in both regions is classified as shorter because it only experiences the rainy season for 4 months, around December to March.

Since mid-2015 until now, Kuatae and Noemeto Villages have received assistance from the central and regional governments through the Village Fund and Village Fund Allocation. The following is information relating to government assistance received by Kuatae and Noemeto Villages during 2016 to 2018. 
Table 3.1. Realization of Revenues and Expenditures of Kuatae and Noemeto Villages in 2016-2018

\begin{tabular}{|c|c|c|c|c|c|c|c|}
\hline \multirow{2}{*}{$\begin{array}{l}\mathbf{N} \\
\mathbf{O}\end{array}$} & \multirow{2}{*}{$\begin{array}{c}\text { Fund } \\
\text { Sourc } \\
\text { e }\end{array}$} & \multicolumn{3}{|c|}{ KUATAE VILLAGE } & \multicolumn{3}{|c|}{ NOEMETO VILLAGE } \\
\hline & & 2016 & 2017 & 2018 & 2016 & 2017 & 2018 \\
\hline 1 & $\begin{array}{l}\text { Villag } \\
\text { e Fund }\end{array}$ & $\begin{array}{c}591,375,5 \\
00\end{array}$ & $\begin{array}{c}762,286,0 \\
00\end{array}$ & $\begin{array}{c}694,359,0 \\
00\end{array}$ & $\begin{array}{c}609,182,0 \\
00\end{array}$ & $\begin{array}{c}776,960,0 \\
00\end{array}$ & $\begin{array}{c}699,121,7 \\
00\end{array}$ \\
\hline 2 & $\begin{array}{l}\text { BHPR } \\
\text { D }\end{array}$ & $4,212,000$ & $3,455,000$ & $5,641,400$ & $4,494,000$ & $3,212,000$ & $5,370,700$ \\
\hline 3 & ADD & $\begin{array}{r}242,026,0 \\
00\end{array}$ & $\begin{array}{r}240,494,0 \\
00\end{array}$ & $\begin{array}{r}254,750,0 \\
00\end{array}$ & $\begin{array}{r}266,256,0 \\
00\end{array}$ & $\begin{array}{r}204,072,0 \\
00\end{array}$ & $\begin{array}{r}259,808,0 \\
00\end{array}$ \\
\hline
\end{tabular}

Based on financial data from the two villages studied, the results of the analysis of the effectiveness of budget absorption indicate that Kuatae and Noemeto villages meet the effective criteria, because they reach $100 \%$. Likewise, an analysis of the effectiveness of the planned activities / programs has all been carried out. Some of the obstacles encountered during the implementation of activities include the implementation time that is not in accordance with the planned schedule, because of inaccurate planning, so it does not take into account the conditions on the ground. The results of the efficiency analysis show that Kuatae and Noemeto villages are still less efficient in managing Village Funds, because the efficiency level is close to $100 \%$. This indicates that the village apparatus is more focused on budget absorption, but the results achieved from each program or activity that were previously planned are still less than optimal.

\subsection{Potential Owned by the Village and Constraints Faced}

Agricultural and plantation products are the main potential possessed by Kuatae and Noemeto villages. For decades, the people of Kuatae and Noemeto Villages have developed a type of food crop that has been cultivated by previous generations with the main product being corn. Other types of plants such as cassava, bananas and beans are developed by the community as an alternative crop in anticipation of crop failure due to erratic weather. Specifically, for vegetables, the people of Kuatae and Noemeto villages already have a market share, in an effort to increase income through the sale of agricultural products in the market. Commodities such as cabbage, shallots, leeks, carrots and kidney beans not only dominate the market in the Regency but also have dominated the supply for several markets in Kupang City, the capital of NTT Province.

Several types of fruit plants in South Central Timor Regency have considerable potential and have economic prospects or values as trade commodities such as avocados, mangoes, guava, papaya, pineapple bananas, jackfruit, soursop, large oranges and watermelons. As it is known that Souk Keprok Orange is one of the leading commodities in the region that must be professionally cultivated to increase the people's income and the economy in the area. Other plantation products that have prospects and potential to be developed include: candlenut, areca nut, coconut and cashew nuts. The agricultural and plantation land of the Kuatae and Noemeto Villages is also possible to be developed into a Tourism Village, where the agricultural land and plantations can be utilized for the development of the agro-tourism industry.

In addition to agricultural and plantation products, Kuatae Village and Noemeto Village are also known as livestock producers in the TTS Regency, especially cattle. The types of large livestock produced consist of cows, horses, buffalo goats, pigs and small livestock / poultry in the form of chickens and ducks. Government assistance through the Village Fund Program has 
been directed at increasing and protecting livestock populations with the aim of increasing livestock production, livestock populations and creating employment. Several activities have been carried out to achieve this goal, namely (1) Prevention and eradication of livestock-borne diseases; (2) Development of animal husbandry technology; and (3) Assistance and counseling for village communities.

The various potential natural resources owned by Kuatae and Noemeto villages should be managed well and responsibly, by utilizing the role of BUMDes. Even though it has great potential in developing the economy of the village community, it has not been utilized optimally, so there are also several obstacles that must be examined and are of concern to the local village officials. These constraints include: lack of public awareness, inadequate human resource capacity, financial governance that has not been transparent, climate and topographic conditions, lack of assistance and training from local government, and inadequate infrastructure. By looking at the existing constraints, it is also hoped that the establishment of BUMDes can be realized soon, so that economic independence in the village can be realized.

\section{Conclusion}

Based on the results of this study, the village government as the subject of development needs to be supported to fulfill basic services to the community, including mobilizing local economic assets. The position of the BUMDes as an institution that gives rise to economic centers in the village with a collective economic spirit, plays an important role although there are still a number of weaknesses inherent in BUMDes, namely:

1. Limited capacity of human resources in the village to manage and develop BUMDes that are accountable and perform well, so that government support is needed in the form of training and assistance for village officials.

2. The low initiative of the local community to drive the local economic potential to improve the social and economic welfare of the villagers, so that an approach from the regional government is needed to build community awareness in actively participating in every activity carried out.

3. The process of consolidation and cooperation between related parties has not yet been developed to realize BUMDes as an economic patron that has a role in advancing the people's economy, so that local government needs support to advance and activate the role of BUMDes optimally.

4. The lack of responsiveness of the Regional Government to make BUMDes a superior program in empowering villages and community welfare, so that it is hoped that the government can encourage the formation and development of BUMDes in each village.

\section{References}

[1] Undang-Undang Nomor 32 tahun 2004 tentang Pemerintahan Daerah.

[2] Undang-Undang Nomor 6 Tahun 2014 tentang Desa.

[3] Kementerian Keuangan Republik Indonesia, 2017. Buku Pintar Dana Desa: Dana Desa Untuk Kesejahteraan Rakyat.

[4] Peraturan Bupati Timor Tengah Selatan Nomor 1 Tahun 2018 tentang Tata Cara Pembagian dan Penetapan Rincian Dana Desa Setiap Desa di Kabupaten Timor Tengah Selatan Tahun Anggaran 2018.

[5] https://timortengahselatankab.bps.go.id/dynamictable/2018/04/09 
[6] http://kupang.tribunnews.com/2019/02/21/optimalisasi-potensi-desa-dalampembangunan-ntt

[7] http://kupang.tribunnews.com/2019/01/29/di-kabupaten-tts-dari-266-desa-baru-95yang-miliki-badan- usaha-milik-desa

[8] Faridah dan Suryono, Bambang. 2015. Transparansi dan Akuntabilitas Pemerintahan Desa Dalam Pengelolaan Anggaran Pendapatan dan Belanja Desa (APBDes). Jurnal Ilmu dan Riset Akuntansi. Surabaya: Sekolah Tinggi Ilmu Ekonomi Indonesia (STIESIA) Surabaya.

[9] Hanifah, Suci Indah dan Praptoyo, Sugeng. 2015. Akuntabilitas dan Transparansi Pertanggungjawaban Anggaran Pendapatan Belanja Desa (APBDes). Jurnal Ilmu dan Riset Akuntansi. Surabaya: Sekolah Tinggi Ilmu Ekonomi Indonesia (STIESIA) Surabaya.

[10] Irma, Ade. 2015. Akuntabilitas Pengelolaan Alokasi Dana Desa (ADD) di Kecamatan Dolo Selatan Kabupaten Sigi. Jurnal. Palu: Universitas Tadulako.

[11] Syaifullah, M. 2017. Understanding of Village Apparatus on Implementation Accounting Villages. International Journal of Science and Research, Vol.6 Issue 8, 1168-1174.

[12] Fatmawati, Ana. 2018. Village Funds Accountability and Misuse Prevention, Indonesian Journal of Business Finance and Accounting, Vol.1 (1), 45-55

[13] Peraturan Menteri Dalam Negeri Republik Indonesia Nomor 113 Tahun 2014 tentang Pedoman Pengelolaan Keuangan Desa.

[14] Mahmudi. 2016. Analisis Laporan Keuangan Pemerintah Daerah. Yogyakarta: Unit Penerbit Dan Percetakan Sekolah Tinggi Ilmu Manajemen YKPN.

[15] Creswell, J. W. (2014). Research Design: Qualitative, Quantitative, and Mixed Method Approaches (4th ed.). London: SAGE Publications, Inc.

[16] Bungin, B. (2012). Penelitian Kualitatif, Komunikasi, Ekonomi, Kebijakan Publik, dan Ilmu Sosial Lainnya (2nd ed.). Jakarta: Prenada Media Grup (Kencana). 